\title{
Tax Enforcement Tools and Tax Compliance in Ondo State, Nigeria
}

\section{Rotimi Oladele (Ph.D)}

Department of Accounting, Faculty of Management Sciences, Federal University, Oye-Ekiti, Ekiti State, Nigeria

\section{Foluso Olugbenga Aribaba (Ph.D)}

Department of Accounting, Faculty of Management Sciences, Federal University, Oye-Ekiti, Ekiti State, Nigeria

\section{Abdul-Lateef Olamide Ahmodu (M.Sc Ed)}

Department of Management Sciences, College of Social \& management Sciences, Wesley University, P.M.B 507, Ondo, Nigeria

\section{Saliu Adeshina Yusuff (M.Sc)}

Department of Management Sciences, College of Social and Management Sciences, Wesley University, P.M.B 507, Ondo, Nigeria

\author{
Muyiwa Alade, (PhD) \\ Department of Accounting, \\ Faculty of Social and Management Sciences, \\ Adekunle Ajasin University, \\ Akungba-Akoko, Nigeria
}

Doi: 10.2478/ajis-2019-0013

\begin{abstract}
This study assessed the effectiveness of tax enforcement tools as panacea for improving tax compliance and overall tax income in the Ondo State, Nigeria. Survey research design was adopted using primary data sourced through administration of structured questionnaire on 150 selected respondents from among staff of Federal Inland Revenue Service and State Board of Internal Revenue Service within the state. The Taro Yamane formula and judgment sampling technique were used to arrive at the sampled respondents. Outcome of Ordinary Least Square regression analysis showed regression coefficient and p-value of taxaudit $(0.278 ; p=0.03<0.05)$ and tax penalty $(0.463 ; p=0.000<0.05)$ respectively, indicating a positive and significant relationship of the two explanatory variables with tax compliance at .05 level of significance. The Implication is that a marginal increase in tax audit and tax penalty will lead to increase in tax compliance in Ondo State. No meaningful association exists between tax amnesty and tax compliance based on the finding of this study perhaps tax amnesty is a new policy that was just launched to encourage voluntary tax compliance. As such, it is imperative that tax audit and imposition of tax penalties be encouraged and sustained. These are envisaged to further improve the degree of tax compliance, consequently enhancing government tax revenue generation to augment dwindling oil revenue in Nigeria. As regards relatively new and still under watch tax amnesty, it may turn out to be a veritable tool for voluntary compliance in future if properly nursed.
\end{abstract}

Keywords: Tax Penalty, Tax Audit, Tax Amnesty, Tax Compliance, and Tax Enforcement 


\section{Introduction}

Effective tax administration plays an important role in generating tax revenue for the government to enable it provides basic amenities that would improve standard of living of the citizenry. Provision of good welfare, infrastructure and maintenance of high standard of living of citizens would be impossible without adequate revenue backing (Anyaduba, Eragbhe \& Kennedy, 2012). Over the years, wide tax gap has been major constraints to tax revenue. Tax gap has been described as the difference between the total amounts of taxes pay voluntarily on time and actual taxes liabilities which is supposed to have been paid for the same period with little or no much effort (John, Emmanuel \& Modugu, 2012). Certainly, the level of tax income generated by the government to meet her spending depends largely on the degree of compliance and the effectiveness of the enforcement tools (Alabede, Ariffin \& Idris, 2011).

Extant literature, most especially in the emerging economies have confirmed that most tax payers do not comply with tax provisions because of lack of trust and even sometimes inability to meet certain obligations (Oyedokun, 2015). Furthermore, some studies affirmed that majority of those that complied partially did so perhaps because of likely penalty that could arise if liability arises after tax audit (Nyaga, 2014; Oyedokun, 2015). Besides, some comply because of fear of possibility of being audited by tax auditors (Anyaduba \& Mogudu, 2013; Ladi \& Henry, 2015). According to Kirchler (2007), noncompliance may take any of the following; not filing of tax return all, understatement of income, overstatement allowable expenses, all with the intension of reducing tax liabilities.

Oyelade (2016), perceived low tax compliance in Nigeria as unpleasant; this is rampart because of ineffective administration encouraged by overreliance on crude oil revenue which resulted to neglect of taxation. Statistical evidences in Nigeria affirmed that, barely ten million taxpayers (precisely 10,006,304) registered under personal income tax in all the States of the Federation, Federal Capital Territory (FCT) inclusive. Surprisingly, about 4.6 million out of these taxpayers are covered by the Lagos State Internal Revenue Service (LIRS) alone. Average of $1.5 \%$ of the rest is under the coffer of each of the 35 States of the Federation including the FCT.

Taking a look at the labour workforce of 77 million at the end of 2015 according to the National Bureau of Statistics (NBS, 2015), with the working force of about 77 million, just about ten million (representing 13\%) are within the tax net. The situation is not too different in the case of corporate income tax payers. With the then finance minister to have quoted that "the rate of compliance is about 12\%" (Olokooba, Awodun, Akintoye \& Adebowale, 2018). Until recent increase in corporate tax registration orchestrated by the current administration, the immediate past finance minister confirmed that over seventy-five percent of registered companies were outside the tax net; worrisome enough that $65 \%$ of those in the tax net hardly file returns nor pay taxes at all. The implication of the above is that less than nine percent of companies operating in Nigeria comply with tax obligation.

Olokooba, Awodun, Akintoye \& Adebowale, (2018) averred that continuous violation of tax laws and persistent rise in low tax compliance has necessitated government at all levels to revisit enforcement strategies for effective tax administration towards improving tax revenue. Abel (2017) affirmed that tax evasion has remained subject of discussion in the Nigerian tax system for a very long period of time possibly because it is one of the major problems confronting effective tax administration in Nigeria. To effectively tackle problems of poor tax administration, government that had recorded remarkable improvement like Lagos State and few other had since employed some tools including tax audit, use of tax penalty and partially adopted tax amnesty when it was introduced. Tax audit involves examination of taxpayers' books of account to ascertain if actual tax returns reflect correct tax payment. Similarly, a tax penalty is a form of deterrence for not complying with tax obligation. For tax amnesty, it is a process that allows voluntary declaration of taxable assets and payment of such outstanding tax liabilities without payment of penalties.

Wang and Hsieh (2015) ascertained that both developed and developing countries have adopted tax amnesty programs. Back since 1980, virtually all the State in the United States has conducted tax amnesty programs. Similarly, Spanish Government announced tax amnesty in 2012 for assets not yet declared and those kept in tax havens. Repatriation of these assets was allowed 
subject to payment of 10 percent tax. This was done to prevent outflow of money from the State. Similarly, Nigeria government in 2017 introduced VAIDS (Voluntary Assets and Income Declaration Scheme) with the objective of benevolent tax amnesty for a limited time to defaulters. The scheme intends to instill fuller tax compliance, payment of outstanding tax liabilities as well as preventing tax evasion (Sam, 2017).

It should be noted that if the amnesties are applied in line with the tax audits and fines, the tax evasion reverse effects can be minimized. Various studies have been conducted to examine the effects of the increased tax audits and penalties on the success of the amnesties. For instance Alm, Mckee and Beck (1990) pointed out that the tax revenues increase except that tax audits and penalties are ineffective. Muhrtala and Ogundeji (2013) were of the view that tax amnesty can improve tax compliance on the ground that strict measures are adopted such as constant tax audits with prosecutions. Similarly, higher audit probability will result in higher level of tax compliance provided that higher tax penalty rate is attached, which is capable of deterring noncompliance. This in turn will increase the amount of participants in tax amnesty program and continuous involvement (Puri, Bambang \& Lukytawati, 2018).

According to Ibrahim (2016), and Onuoha and Dada (2016), various enforcement measures are available when voluntary compliance seems difficult. These include tax audit, tax penalty and even tax amnesty and sometime tax holidays (Anah \& Nwaiwu, 2018). There are other tax enforcement tools such as tax audits, placement of tax penalties and fines, detainment of assets and subsequent disposal of tax default property, and compulsory use of tax clearance certificate for major transactions (Samuel, 2015). Thus, extant literature have suggested that nexus subsists between the aforementioned tax enforcement tools and tax compliance.

Moreover, the challenge evinced in tax compliance and collections have been worrisome. Out of the myriad of challenges bedeviling tax collection in Ondo State are unclear tax regulations, ineffective tax administration and inadequate public enlightenment about tax matters. Whereas, studies certain have established inverse relationship between administration (tax enforcement tools) and tax compliance most especially among the States that hardly survive with meager Federal allocations they receive due to dwindling oil revenue. Further, despite all efforts by previous administrations to improve tax revenue, tax proceeds have remained abysmally low and continue to shrink over the years.

As such, this study was embarked upon with the central objective to access the degree at which effectiveness of tax audit, tax penalty and tax amnesty in the case of Ondo State, Nigeria influence tax compliance as a precursor for improving tax revenue.

\section{Conceptual Clarification and Theoretical Review}

\subsection{Tax Enforcement}

Enforcement in administration of taxes plays very crucial role in enhancing tax compliance. Enforcement task involves the use of myriad of tools in ensuring tax compliance. The essence of enforcement is to ensure strict adherence to various tax compliance ranging from timely filing, accurate filing, to payment of tax liability as at when due. Primarily, enforcement is not for tax defaulters alone who fail in their tax responsibilities but to consistent filers to encourage continuous compliance (Ibrahim, 2016).

Tax compliance mechanisms may take various forms depending on tax authorities. In modern day, more than often, compliance tools may include levies, search and seizures of defaulting tax payers, fines, seeking and obtaining information from third parties like banks and court actions. Tax enforcement ordinarily refers to an act of ensuring that tax payer comply with tax law or rule. Enforcement with tax administration takes two forms namely; enforcement of tax laws and enforcement of judgment. There is enforcement of tax which is the application of all those relevant laws that will assist the tax authorities in carrying out their duties, not laws necessarily relating to the taxation but are relevant to the enforcement of tax laws. Enforcement of judgment on the other hand represents already decided court case against defaulted tax payment (Macharia, 2014). In Nigeria tax system, tax administration may not be efficient without tax enforcement because of the 
sharp practices among larger percentage of taxpayer.

Marziana, Mohamad, Norkhazimah and Mohmad (2010) affirmed tax compliance is the level at which a taxpayer complies or default the tax rules of their country. One of the primary objectives of an effective tax administration in any country is to attain the degree of tax compliance best capable of reducing tax gap while maximizing tax revenue to the topmost. Roth, Scholtz and Witte (1989) reiterated that compliance with reporting requirement signifies that the taxpayer files all required tax returns timely and that the returns correctly report tax liability in line with the Internal Revenue code, tax laws and possibly court decisions if any, applicable at the time the return is filed. This demarcates clearly the line between tax compliance and noncompliance.

A taxpayer may unintentionally fail to adhere to tax rules while filling his tax form/returns, or better still deliberately decided to pervade tax rule to suppress his tax liabilities even right from the onset. The outcomes are the same whether an honest or dishonest mistake are made. Underreporting or over reporting may result. Theory submitted that tax evasion is the deliberate act of noncompliance with the tax law with the aim of reducing tax liability. Better still, failure to comply with tax reporting requirements could be as a result of mistakes, negligence, misinformation, or misunderstanding, or all.

\subsection{Tax Audit and Tax Compliance}

One of the determinants of tax compliance that determines the level of tax compliance which attracts prominence in tax compliance literature is tax audit. The degree of tax audit relies on two factors: the number of taxpayers flagged for audit and, its intensity and thoroughness of the audit. The first element is measured as the number of taxpayer audit conducted divided by the overall number of taxpayers. Tax audit is employed to determine the degree of tax audit for practical comparison and analysis (Adeniran, Alade \& Oshode, 2013; Ladi \& Henry, 2015). Administration cost is required during tax audit. An increase in the level of tax audit is advocated to reduce the amount of other administrative activities, such as taxpayer service, collection of taxes (Ibrahim, 2016).

Mahfar (1994) and Oyedokun (2015) averred that tax audit becomes expedient, going by the rising degree of non-compliance prevalent among developing countries of the world. Tax audit is required to compel defaulting corporate bodies, individuals and even charities organizations to drag them back to full compliance. Non-compliance is feasible in failure to remit tax deduction, not filing tax returns, under-reporting of income, over-statement of deductions, or failure to pay the correct tax liabilities (Oyedokun, 2015; Ojonta, 2011; Mahfar, 1994). Tax audit is therefore an established tool to ventilate tax compliance.

According to Okonkwo (2014), as cited by Onuoha and Dada (2016) refers to tax audit as an independent examination of book of accounts, tax returns, tax payments and other records of a taxpayer to confirm compliance with statutory tax requirement, rules and regulations and accuracy and correctness of tax paid and adhering to the relevant generally accepted accounting principles and standards. Anah \& Nwaiwu (2018), sees tax audit as an examination of an individual or entity's tax report by the relevant tax authorities in order to find out compliance with applicable tax laws and regulations of the state. However, the rate of recurrence of tax audits and investigations, in recent times, by the Federal Inland Revenue

Service (FIRS) and the various State Boards of Internal Revenue (SBIR) have been on the increase (Ibrahim, 2016).

\subsection{Tax Penalties/Fines and Tax compliance}

The degree of penalty system may be different from one country to another: The rate of penalty is usually applied by the various tax authorities to determine penalty payable by defaulting tax payers (Ladi \& Henry, 2015). Also, the types of evasion depend on penalty rate to be applied. For example, late filling of returns, normal filing with shortened-reporting, refusal to keep records of source documents like invoices and receipts attract different penalty rate behaviour (Chirkos, 2015). With intentional evasion, the rate of penalty is greater than those of non-deliberate evasions (Hyun, 
2005). This system might play an important role in increasing the level of penalty rates for the behaviour of tax evasion.

There has not been correlation between statistics and theoretical findings as regards the effect of fines on tax compliance. Hyun (2005), confirmed that relationship between fines and tax compliance also shows inconsistent findings. The study of Park and Hyun (2005) indicated that tax compliance reacts better to fines than it does to audit possibility. Friedland, Maital and Rutenberg (1978), posited that holding constant the anticipated tax but altering audit probabilities with fines for non-compliance, compliance moves up appropriately with risen fines, but not with higher audit probabilities. Other result of similar studies post different pictures. Brautigam, Old-Heldge and Mick's (2008) result showed that fines and tax compliance are not related, but audit probabilities and tax compliance are. In an antagonistic climate, fines can be a part of the game of "cops and robbers". In a synergistic climate, they can be perceived as an adequate retribution for behaviour that harms the community. Fines react to trust and power.

\subsection{Tax Amnesty and Voluntary Tax Compliance}

Osman \& Eren (2011) stressed that tax amnesty is the act of reducing or eliminating completely a definite or an indefinite punishment by authoritative governmental bodies through the tax authorities. Amnesty ordinarily means "to renounce a right". It represents the "legal deals" which removes the right to place a penalty; and prevent; either partially; and or completely, the execution of a penalty for the criminal acts. Tax amnesty removes the penalties or punishments to be executed against tax defaulters (Ojochogwu, 2012). Wang \& Hsieh (2015) affirmed that tax amnesties have been adopted repeatedly by many developed as well as developed countries such as the US, Italy and Argentina and had yielded desired results. According to Osman and Eren (2011), tax amnesty program varies from one country to another as well as covering some specific taxes. Tax amnesty has been found to be controversial tax compliance tool because while large revenue was generated in some countries; it failed woefully in others countries (Torger, 2003).

In the case of Nigeria, government on 1 July 2017, introduced tax amnesty called "VAIDS" for defaulting taxpayers to use the said window to normalize their tax status. The Scheme which was to ensure full compliance within a reasonable period of nine-month window; and ceased on 30 March 2018, was later extended to 30 June 2018. Defaulting taxpayers during period were expected to declare their assets and income from source within and outside country for the past six years covering 2011 - 2016 years of assessment (YOA). This was also meant to regularize their tax status and ensured total compliance.

\section{Theoretical Review}

\subsection{Economic Utility/Deterrence Theory}

The contemporary revival of the economic analysis of crime began in 1968 with Becker's' classic article on crime and punishment. While Becker mentioned tax evasion as an area of application for his general model, Allingham and Sandmo (1972), provided the analysis. Generally, this approach treats noncompliance as a rational individual decision based upon probabilities of detection, conviction and levels of punishment. Deterrence theory is concerned with the effects of sanctions and sanction threats on criminal or undesirable behaviour. Deterrence theory was used as a basis to examine many types of criminal behaviour including tax evasion (Mohammed, 2015).

\subsection{Neoclassical Theory}

Before, neoclassical theorists had discussed tax amnesty in length economist, neoclassical economists have examined the impact of tax amnesties from various perspectives. Alm and Beck (1993) equally demonstrated that amnesties may influence compliance and tax collections, most especially if it is the social norm of the tax payers to pay taxes and the amnesty is subsequently followed by effective enforcement drives. Amnesty may truncate tax revenues in the long-run 
because of the likely reduction in tax compliance. Ability of tax amnesties to generate tax revenues in the long run is ambiguous, vague and unclear hence, tax amnesties are short-term revenues oriented. The study of Andreoni (1991) examined tax amnesties and tax compliance and found that evasion increases during the amnesty periods but tax revenue does not necessarily fall. Reasons, tax evasion graduates to the extent to which people expect and are willing to participate in the tax amnesty and they will be to be recaptured new evader not the existing one who do not participate at all in the amnesty. From the above, the substance of the two theories; deterrence and neoclassical theories are both concerned about ensuring compliance, hence the study is anchored on these theories.

\section{Methodology}

Survey method of research design was employed to achieve the objectives of the study. The target population consists of 243 staff of Federal Inland Revenue Service and State Internal Revenue Service in Ondo State. Taro Yamen's formula was adopted to arrive at the sample because of the population is heterogeneous in nature, this assist us to obtain meaningful sample size. We deliberately used judgmental sampling techniques to select the sample of 150 respondents from among senior and junior staff of Federal Inland Revenue Service and State Internal Revenue Service; these are those working directly in tax assessment and collection units and we ensure close monitoring to ensure all copies of questionnaire were retrieved. This was possible because of compact nature of the population of study.

$$
\begin{aligned}
& n=\frac{N}{1+N(e)^{2}} \\
& \text { Where } \mathrm{N}=\text { Population size } \\
& \mathrm{n}=\text { sample size } \\
& \mathrm{e}=\text { Level of significance }(0.05) \\
& n=\frac{243}{1+243(.05)^{2}} \\
& =\frac{243}{1.6075} \\
& =150.4 \\
& =150
\end{aligned}
$$

The ordinary least square regression technique was employed to test the hypothesis of the study. The face validity and content validity of the questionnaire were verified to ensure that the questionnaire contains questions that measure the construct as well as covering covers all crucial aspect of the construct (Cooper \& Schindler, 2008). Also, we established reliability of the instrument through a test and retest method, copies of questionnaire were administered, two weeks after collection, the same instrument were administered to the respondent thereafter, this test was used to determine the consistency and reliability respondents' responses. Spearman reliability coefficient was also adopted to ascertain the reliability of the instrument. Therefore, the following propositions were investigated:

Hypothesis 1: There is no significant relationship between tax audit and tax compliance in Ondo State.

Hypothesis 2: There is no significant relationship between tax penalty and tax compliance in Ondo State.

Hypothesis 3: There is no significant relationship between tax amnesty and compliance in Ondo State.

\subsection{Model Specification}

In order to ascertain impact of tax enforcement tools on tax compliance in Ondo State a regression model was adopted since the variables of study are economic variable that are somehow dependent on one another. Therefore the general framework is as specified below:

TAXCOMP $=\beta 1$ TAXAUDIT $+\beta 2$ TAXPEN $+\beta 3$ TAXNESTY $+\varepsilon$

Where; 
TAXCOMP - Tax compliance

TAXAUDIT - Possibility of audit

TAXPEN - Tax penalty

TAXNESTY - Tax amnesty

$\varepsilon$-Error term

\section{Results and Discussion}

This section presents results of the analysis performed based on data collected. To start with, Table 1 depicts results of reliability test using Cronbach's alpha.

\subsection{Reliability Test}

Cronbach's alpha $(\alpha)$ reliability testing tool was applied to examine the consistency and reliability of the research instrument. Table 1 shows the estimate of the Cronbach alpha to test for the reliability of the five-point Likert scale employed in this study so as to prevent spurious and invalid analysis. The findings recorded a fairly high Cronbach value of 0.756 which depict a consistent result.

Table 1: Reliability Statistics

\begin{tabular}{|c|c|}
\hline Cronbach's Alpha & Number of Items \\
\hline 0.756 & 20 \\
\hline
\end{tabular}

Source: Authors computation

Table 2 presents frequency and percentage of responses on tax audit and tax compliance. Results of the six-item questionnaire in this regard showed that tax audit has proclivity to drive tax compliance based on the submission of the tax officials. This is demonstrated by the position of the officials who majorly agree and strongly agree in each case that exposure to tax audit compels accurate reporting, improved tax payers' cooperation, adequate tax returns, expose tax irregularities, and the existence of standardized program that support tax audit, thereby informing improved tax compliance.

Table 2: Tax audit and tax compliance

\begin{tabular}{|c|c|c|c|c|c|}
\hline & 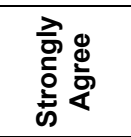 & $\begin{array}{l}\frac{\Xi}{2} \\
\frac{2}{4}\end{array}$ & 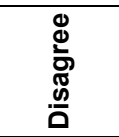 & 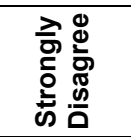 & 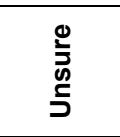 \\
\hline $\begin{array}{l}\text { There is possibility of been exposed by tax audit } \\
\text { and this compels accurate reporting }\end{array}$ & $90(60 \%)$ & $45(30 \%)$ & $6(4 \%)$ & $5(3 \%)$ & $4(3 \%)$ \\
\hline $\begin{array}{l}\text { Tax audit exercise witness corporation of tax } \\
\text { payer }\end{array}$ & $32(21 \%)$ & $71(47 \%)$ & $17(11 \%)$ & $9(6 \%)$ & $21(14 \%)$ \\
\hline $\begin{array}{l}\text { Tax payers file adequate tax returns because of } \\
\text { fear of tax audit }\end{array}$ & $61(40 \%)$ & $39(26 \%)$ & $30(20 \%)$ & $10(7 \%)$ & $10(7 \%)$ \\
\hline Regular tax audit influence tax compliance & $38(25 \%)$ & $62(41 \%)$ & $23(15 \%)$ & $13(8.7 \%)$ & $14(9 \%)$ \\
\hline $\begin{array}{l}\text { Tax irregularities would be uncovered during tax } \\
\text { audit }\end{array}$ & 4 & 6) & $31(21 \%)$ & $12(8 \%$ & $6(4 \%)$ \\
\hline $\begin{array}{l}\text { Tax authorities have standardized program that } \\
\text { aid successful tax audit }\end{array}$ & $47(31 \%)$ & $59(40 \%)$ & $20(13 \%)$ & $8(5 \%)$ & $16(11 \%)$ \\
\hline
\end{tabular}

Source: Field Survey, 2018.

Concerning possible association between tax penalties and level of tax compliance among tax payers in the State, seven-item based questionnaire was used. The descriptive results as shown in 
Table 3 unveiled that Fear of being penalized, especially when caught, which can also lead to sealing up of the tax payers' properties were confirmed by the larger proportion of the respondents as restraints informing increase in tax compliance. But most of the respondents are of the opinion that the present tax penalties are not deterrent enough to instill tax compliance among the tax payers while a considerable number of the tax payers are not familiar with tax penalties. This suggests need for further tax penalties education to the tax payers by tax authorities to enhance the level of tax compliance.

Table 3: Tax penalties and tax compliance

\begin{tabular}{|c|c|c|c|c|c|}
\hline & 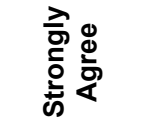 & 迹 & 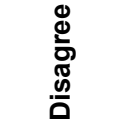 & 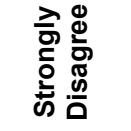 & 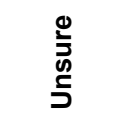 \\
\hline $\begin{array}{l}\text { Fear of being penalized will propel tax payer to } \\
\text { file accurate and timely return }\end{array}$ & $101(67 \%)$ & $33(22 \%)$ & $7(5 \%)$ & $5(3 \%)$ & $4(3 \%)$ \\
\hline $\begin{array}{l}\text { Present tax penalties are not deterrent enough } \\
\text { to instill tax compliance }\end{array}$ & $23(15 \%)$ & $58(39 \%)$ & $36(24 \%)$ & $11(7 \%)$ & $22(15 \%)$ \\
\hline $\begin{array}{l}\text { Tax offenders will choose to pay tax penalty } \\
\text { rather than payment of actual tax liabilities }\end{array}$ & $14(9 \%)$ & $36(24 \%)$ & $43(29 \%)$ & $47(31 \%)$ & $10(7 \%)$ \\
\hline $\begin{array}{l}\text { Good numbers of tax payers are not familiar } \\
\text { with tax penalties otherwise they would have } \\
\text { complied }\end{array}$ & $46(31 \%)$ & $47(31 \%)$ & $30(20 \%)$ & $11(7 \%)$ & $16(11 \%)$ \\
\hline $\begin{array}{l}\text { Tax payers know they may not escape payment } \\
\text { of penalty once detected hence, the need to } \\
\text { comply }\end{array}$ & $71(47 \%)$ & $36(24 \%)$ & $30(20 \%)$ & $4(3 \%)$ & $9(6 \%)$ \\
\hline $\begin{array}{l}\text { Sealing up tax payer properties as a form of } \\
\text { penalty increases tax compliance }\end{array}$ & $46(31 \%)$ & $57(38 \%)$ & $25(17 \%)$ & $15(10 \%)$ & $7(5 \%)$ \\
\hline $\begin{array}{l}\text { Tax penalties will bring lasting solution to } \\
\text { noncompliance problem. }\end{array}$ & $55(37 \%)$ & $32(21 \%)$ & $25(17 \%)$ & $11(7 \%)$ & $27(18 \%)$ \\
\hline
\end{tabular}

Source: Field Survey, 2018.

As regards 7-item measure used to investigate ability of tax amnesty to ensure tax compliance as presented in Table 4, generally over $50 \%$ of the respondents submitted that tax pardon, exclusion from prosecution for tax offences, and waiver of penalties and interest charges possess latency to improve level of tax compliance. Above average of the tax officials also believe that tax amnesty has potential to reduce tax defaulters, propels declaration of all assets and income against inappropriate tax assessment leading to expansion of tax net capable of improving the rate of tax compliance, consequently ameliorating tax evasion. This descriptive result is a pointer that tax amnesty has propensity to inculcate willingness to comply with tax requirements by the tax payers.

Table 4: Tax amnesty and tax compliance

\begin{tabular}{|c|c|c|c|c|c|}
\hline & 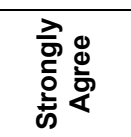 & 恣 & 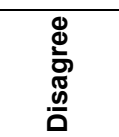 & 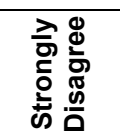 & 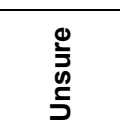 \\
\hline $\begin{array}{l}\text { Tax pardon encourages tax payer's voluntary } \\
\text { declaration of all their income and assets }\end{array}$ & $81(53 \%)$ & $40(27 \%)$ & $12(8 \%)$ & $10(7 \%)$ & $7(5 \%)$ \\
\hline $\begin{array}{l}\text { Exclusion from prosecution for tax offence } \\
\text { causes tax payer to pay their outstanding tax } \\
\text { liabilities }\end{array}$ & $33(22 \%)$ & $57(38 \%)$ & $33(22 \%)$ & $17(11 \%)$ & $10(7 \%)$ \\
\hline $\begin{array}{l}\text { Waiver of penalties and interest charges } \\
\text { encourage tax payer to comply with tax } \\
\text { obligation }\end{array}$ & $49(33 \%)$ & $40(27 \%)$ & $27(18 \%)$ & $17(11 \%)$ & $17(11 \%)$ \\
\hline
\end{tabular}




\begin{tabular}{|l|c|c|c|c|c|}
\hline $\begin{array}{l}\text { Many tax defaulters employed recently } \\
\text { concluded tax amnesty to reconcile their tax } \\
\text { default with tax authorities }\end{array}$ & $37(25 \%)$ & $64(43 \%)$ & $28(19 \%)$ & $10(6 \%)$ & $11(7 \%)$ \\
\hline $\begin{array}{l}\text { Declaration of all assets and income will further } \\
\text { prevent tax defaulter from inaccurate tax } \\
\text { assessment }\end{array}$ & $46(31 \%)$ & $48(32 \%)$ & $38(25 \%)$ & $13(9 \%)$ & $5(3 \%)$ \\
\hline $\begin{array}{l}\text { Expansion of tax net with the aid of tax } \\
\text { amnesty will improve compliance and increase } \\
\text { tax revenue }\end{array}$ & $35(23 \%)$ & $62(41 \%)$ & $28(19 \%)$ & $11(7 \%)$ & $14(10 \%)$ \\
\hline $\begin{array}{l}\text { After tax amnesty, the perception of being } \\
\text { already in tax net deters tax evasion }\end{array}$ & $59(39 \%)$ & $51(34 \%)$ & $14(9 \%)$ & $6(4 \%)$ & $20(133 \%)$ \\
\hline
\end{tabular}

Source: Field Survey, 2018.

Table 5: Ordinary Least Square (OLS) regression estimates

\begin{tabular}{|l|c|}
\hline Dependent variable & TaxCOM \\
\hline TaxAUD & $0.278^{\star *}(0.030)$ \\
\hline TaxPEN & $0.463^{\star * *}(0.000)$ \\
\hline TaxAMN & $0.003(0.977)$ \\
\hline$C$ & $4.734^{\star * *}(0.000)$ \\
\hline$R^{2}$ & 0.543 \\
\hline Adjusted $R^{2}$ & 0.529 \\
\hline
\end{tabular}

\section{Source: Authors' Computation}

The regression results comprise the OLS estimates, important statistics like $R^{2}$ and adjusted $R^{2}$. The coefficient of determination ( $R$ squared) of $54 \%$ revealed the variation in tax compliance as a result of the three independent variables (tax audit, tax penalty and tax amnesty) leaving other $46 \%$ of the variables outside the study. The results recorded existence of positive relationship between tax audit and tax compliance in line with the finding by Modugu and Anyaduba (2014). Invariably, tax audit impacts positively on tax compliance significantly at $5 \%$ level. In addition, the significant coefficient is 0.278 which implies that a $1 \%$ increase in tax audit will cause tax compliance to rise by $0.278 \%$ consistently Nyaga (2014) from Kenya but at a reduced proportion. Therefore, the more the tax audit, the likelihood of more compliance to tax regulations; this was supported by $p$-value of $0.03<0.05$ level of significance.

In the same vein, findings also reported a positive relationship between tax penalties and tax compliance with a regression coefficient of 0.463 which confirmed the position of Park and Hyun (2005), and Friedland, Maital and Rutenberg (1978) that penalty is more related to tax compliance than tax audit contrary to Devos (2004). Also, the p-value of $0.000<0.005$ confirms the significance of tax penalty. The implication here is that an increase of $1 \%$ in tax penalties results in $0.463 \%$ rise in tax compliance. Instituting sustainable tax penalties regime best capable of deterring tax evasion will compel compliance as well as increasing tax revenue. In the case of tax amnesty, a positive (invariantly with Saidimu's (2009) study from Kenya) but weak relationship between tax amnesty and tax compliance exists. This was evinced in regression coefficient of 0.003 and $p$-value of $0.977>0.05$ (statistically insignificant). As such, the results show that tax amnesty may form an effective tool for enhancing tax compliance now but possibly in the future.

Table 6: ANOVA ${ }^{\mathrm{a}}$

\begin{tabular}{|l|l|c|c|c|c|c|}
\hline \multicolumn{2}{|l|}{ Model } & Sum of Squares & Df & Mean Square & F-Stat & Sig. \\
\hline \multirow{2}{*}{1} & Regression & 855.542 & 3 & 285.181 & 25.381 & $.000^{b}$ \\
& Residual & 1640.458 & 146 & 11.236 & & \\
\hline
\end{tabular}

a. Dependent Variable: Tax Compliance

b. Predictors: (Constant), Tax Penalty, Tax Amnesty, Tax Audit. Source: Authors computation $f$ 
ANOVA analysis was carried out to check the validity and significance of the model. Table 6 depicts the ANOVA results to test the significance of the overall model. With an F-statistics of 25.381, the results show that the model is significant at $1 \%$ level of significance since the $p$-value is 0.000 .

\subsection{Hypotheses Testing}

\subsubsection{Hypothesis 1: There is no significant relationship between tax audit and tax compliance in Ondo State.}

With regression result; regression coefficient of 0.278 and $p$-value of $0.03<0.05$, it is confirmed that significant and positive relationship exists between tax audit and tax compliance at $5 \%$ level of significance. Therefore, we reject the null hypothesis that there is no significant relationship between tax audit and tax compliance, thereby confirming applicability of deterrence theory. Thus we accept the alternative hypothesis. This finding is in tandem with that of Nyaga (2014) from Kenya, and Modugu and Anyaduba (2014) from Nigeria.

\subsubsection{Hypothesis 2: There is no significant relationship between tax penalty and tax compliance in Ondo State.}

Also, with $p=0.000<0.05$ and regression coefficient of 0.463 , a significant and positive relationship has been observed. Hence, we reject the null hypothesis that there is no significant relationship between tax penalty and tax compliance. Thus we accept the alternative hypothesis. This submission is in consonance with that of Anyaduba and Modugu (2013) but at variance with Soyinka, Jinadu and Sunday (2016) that employed similar survey research design to gather data used. It is established further that tax penalty serves as deterrent to enhance tax compliance in line with deterrence theory.

\subsubsection{Hypothesis 3: There is no significant relationship between tax amnesty and compliance in Ondo State.}

Here, $p=0.977>0.05$ and regression coefficient of 0.003 symbolized very weak or even lack of relationship at all between tax amnesty and tax compliance in Ondo State at $5 \%$ level of significance. Therefore, we accept the null hypothesis which stated that there is no significant relationship between tax amnesty and tax compliance, providing further support to the finding by Andreoni (1991) but contrary to the submission by Benk (2016). This submission is at variance with the theoretical guess by Alm and Beck (1993) that amnesty may influence tax compliance. Thus, we accept the null hypothesis. However, this unique finding may not be dissociated from the fact that the scheme was relatively new the Nigerian tax system.

\section{Conclusion and Recommendation}

This study examined three major tax enforcement tools being employed to enhance tax compliance in Ondo State, Nigeria. Though there are other tools but the three instruments, namely; tax audit, tax penalties and tax amnesty were examined. It was found that these variables to certain extent influence tax compliance in Ondo state at different degrees for now with the exception of tax amnesty that has just been launched through VAID, which negates neoclassic economists' position that amnesty may influence compliance. Other two variables (tax audit and tax penalties) were found to be statistically significant and could induce tax compliance varying levels in accordance with deterrence theory. Whereas there is statistical but not significant relationship between tax amnesty and tax compliance.

Therefore, this study concludes that low tax compliance is a matter of serious concern in Nigeria most especially in Ondo State because it decimates tax revenue of government and reducing its financial capability to meet developmental purposes. The gap created by low tax compliance is enormous. Since the tax revenue derivable by government to meet social and 
developmental need of citizenry depends largely on the degree of tax compliance by tax payer most importantly now that oil revenue has declined, then government should adopt every workable strategy to ensure voluntary compliance or otherwise its time it uses the big arms of the law inherent in penalty to compel compliance. Fear of tax audit and possibility of resultant penalties have recorded successful compliance in Lagos state, Nigeria for instance, hence will yield similar results in Ondo State and possibly in other States of the Federation.

It is recommended that regular tax audit should be entrenched most especially on major tax payers and high net worth citizens that mostly indulge in tax evasion. Constant tax audit will assist to detect fraudulent, incorrect and or underreporting of taxable incomes. Although it would not be feasible to conduct tax audit on all tax payers, the fear of a regular tax audit instills the fear of tax defaulters being apprehended one day. Similarly, tax penalty should be stiff enough to serve as deterrent to would-be tax defaulters; also, ability to pay principle should be encouraged. Tax amnesty should not be jettisoned for now as it may create a laudable avenue for enlarged tax net in the future. Tax education is recommended to further enlighten people about the need to fulfill tax obligations even right from the schools. Staff training especially in the area new technology is very important. In all, tax officers' welfare should be reviewed upward to motivate them for transparency. Government should demonstrate sincerity in the use of tax income as this would further boost the tax payers' trust in governance; these and many more would engender willingness to comply with tax obligation in Nigeria. Future study is encouraged investigate tax payers' position in this regard, while the use of secondary data may be sought to further ventilate the submission of this study.

\section{References}

Adediran, S.A., Alade, S.O., \& Oshode, A.A. (2013). The impact of tax audit and investigation on revenue generation in Nigeria. European Journal of Business and Management, 5(26), 159-160.

Alabede, J.O., Ariffin, Z.Z., \& Idris, K.M. (2011). Individual taxpayers' attitude and compliance behaviour in Nigeria: The moderating role of financial condition and risk preference. European Journal of Economics, Finance and Administrative Sciences, 3(5), 91-104,

Allingman, M., \& Sandmo, A. (1972). Income tax evasion: A theoretical analysis. Journal of Public Economics, $1,323-338$

Alm, J., Mckee, M., \& Beck, W. (1990). Amazing grace: Tax amnesties and compliance. National Tax Journal, 43.

Amah, C.O., \& Nwaiwu, J.N. (2018). Tax audit practice and down south tax revenue generation in Nigeria. International Journal of Innovative Finance and Economics Research 6(1):99-112

Andreoni, J., Erard, B., \& Feinstein, J. (1998). Tax compliance. Journal of Economic Literature. 36: 818-860

Anyaduba, J.O., Eragbhe, E., \& Kennedy, P.M. (2012). Deterrent tax measures and tax compliance in Nigeria. Journal of Business and Management, 4(11), 99

Bătrancea, L., Nichita, R., \& Bătrancea, L. (2012). Understanding the determinants of tax compliance behavior as a prerequisite for increasing public levies. The USV Annals of Economics and Public Administration 12,1(15), $201-210$

Brautigam, D., Odd-Helge, F., \& Mick, M. (2008). Taxation and state-building in developing countries: capacity and consent. Cambridge: Cambridge University Press.

Chirkos, A.Y. (2014). A Comparative study of compliant and non-compliant individual taxpayers in Ethiopia evidence from Amhara region. Journal of Economic and Sustainable Development. 5(24) 10

Jame, B. (2014). Tax enforcement: Investigation and litigation under Nigerian tax laws: raising the standards and protecting rights and responsibilities Part 1. Retrieved from http:// www.peopledaily.com

Ibrahim, A. (2016). An examination of tax administration and enforcement mechanisms under the Federal Inland Revenue Service Act, 2007, (Post graduate dissertation studies), Ahmadu Bello University Zaria.

Kirchler, E. (2007). The economic psychology of tax behavior. Cambridge: Cambridge University Press.

Ladi, O.M. \& Henry, I.T. (2015). Effects of tax audit on revenue generation: Federal Inland Revenue Service. Journal of Good governance on sustainable development in Africa, 2(4): $67-80$

Macharia, J. K. (2014). The effect of tax Evasion on tax revenues in Kenya (Unpublished MBA Project), University of Nairobi.

Michael, J.B. (2011). Challenges of tax authorities: Tax payers in the management of tax reform processes. The Nigeria Accountant, 42 (2), 36-38

Mohammed, B. T. (2015). Tax law enforcement: Practice and procedure research. Journal of Finance and Accounting, 6(7), 143-147 
Marziana, H., Mohamad, N., Orkhazimah, A., \& Mohmad, S.D. (2010). Perceptions of taxpayers with level of compliance: A comparison in the East Coast Region, Malaysia. Journal of Global Business and Economics, 1(1), 241-257

Muhrtala O.T., \& Ogundeji, M. (2013). Professionals' perspective of tax evasion: some evidence from Nigeria, Universal Journal of Accounting and Finance, 1(2), 35-41

Nicoleta, B.M. (2011). A review of factors for tax compliance. Economics and Applied Informatics, 1(1) 70-76

Ojochogwu, W. A., \& Stephen, A. O. (2012). Factors that affect tax compliance among small and medium enterprises (SMEs) in North Central Nigeria. International Journal of Business and Management, 7(12), 87-96

Ojonta, B.A. (2011). Tax audit and investigation in Enugu State, Nigeria, University of Nigeria Nsuka

Okonkwo, A.I. (2014). Critical evaluation of tax audit and investigation processes in enhancing tax compliance: Being a paper presented at the CITN MPTP in Uyo on October 8-9.

Olokooba, S. M., Awodun, M., Akintoye, O.D., \& Adebowale, H.I. (2018). Tax offences: clogs in the wheel of progress and development of Nigeria as a nation. International Journal of Law and Jurisprudence, 9(1) 226

Onuoha, L.N., \& Dada, S.O. (2016). Tax audit and investigation as imperatives for efficient tax administration in Nigeria. Journal of Business Administration and Management Sciences Research, 5(5), 066-076,

Osman, F. S., \& Eren, Ç. (2011). Tax amnesty with effects and effecting aspects, Tax compliance, tax audits and enforcements around the Turkish Case. International Journal of Business and Social Science, 2(7), 95

Oyelade, T. (2016). Guess how many Nigerians pay tax and how our government spends the money. Retrieved from http:// www.pwenigeria.typepad.com

Roth, J. A., Scholtz, J. T., \& Witte, A. D. (1989). Tax payer compliance: An agenda for research. Philadelphia. University of Pennsylva.

Puri, M., Bambang, J., \& Lukytawati, A. (2018). The determinants of tax compliance in Tax Amnesty programs: Experimental approach, Etikonomi, 17(1), 93-110

Sam, D. (2017). Breaking resistance to voluntary tax compliance. (Retrieved from www.leadershipnews.com

Samuel, K.N., (2015). The Effect of Enforcement Measures on Value Added Tax Revenue for Firms in the Large Corporate Taxpayer Category in Kenya (Master of science in finance, school of business, university of Nairobi).

Torgler, B. (2003). Tax morale, rule-governed behaviour and trust. Constitutional Political Economy, 14(2), 119140

Wang, Y., \& Hsieh, W. (2015). A fairness approach to tax amnesty. Journal of Accounting and Taxation, 7(2), 19-28 